CASE REPORTS

\title{
DWARFISM WITH RETINAL ATROPHY AND DEAFNESS
}

\author{
BY \\ E. A. COCKAYNE, D.M., F.R.C.P. \\ Consulting Physician to the Middlesex Hospital; Consulting Physician to the Hospital for \\ Sick Children, Great Ormond Street
}

In 1936 I described a sister and brother under this title. At that time they were invariably goodtempered, quick in their movements, and very excitable, laughing much more readily than children of normal mentality.

Their mental and physical state has changed very considerably during the last nine years and, since no description of the condition has been found in medical literature, I think their present state should be placed on record. A more complete family history is now available and the weight of the children at birth and during the first two years of life has been obtained from the Infant Welfare Centre at Woolton Hill.

The maternal grandfather was about $5 \mathrm{ft}$. in height, the maternal grandmother taller; they had nine children, the first was a male more than $6 \mathrm{ft}$. in height, who had four children, two sons and two daughters, all big and normal; the second a female, $5 \mathrm{ft}$. high, who had a son $6 \mathrm{ft}$. high; the third a female, $5 \mathrm{ft}$. high, who had a normal son and daughter; the fourth a male nearly $6 \mathrm{ft}$. high, who had two sons and a daughter, all tall; the fifth a female, $5 \mathrm{ft}$. high with no children; the sixth a male, $4 \mathrm{ft} .6 \mathrm{in}$. high, who had seven children, a son, three daughters, a son, and two daughters, the second daughter being $4 \mathrm{ft}$. 6 in. and the fifth tall; the seventh child was Mrs. D., $5 \mathrm{ft} .1$ in., whose children, the subject of the paper, will be described subsequently; the eighth child, a male, $6 \mathrm{ft}$. 4 in. high, had ten children, at least six of them boys, all rather tall; the ninth child, a male, $6 \mathrm{ft}$. high, had no children. Mrs. D. had eight children, the first three were daughters, all tall, the second being the tallest of the sibship, the fourth was a son as tall as the third daughter, then came Pearl and David, followed by a daughter, who died in infancy, followed by a son, aged thirteen, who is already taller than his mother. Mr. D., who says he is not a blood relation of his wife, was about the fifth of a sibship of nine or ten, most of whom were of average height, though one was very small and became a jockey.

Pearl D., born July 11, 1927, weighed $6 \mathrm{lb} .12 \mathrm{oz}$. at birth, $16 \mathrm{lb} .13 \mathrm{oz}$. at one year, $20 \mathrm{lb}$. at two years, and $23 \mathrm{lb}$. at three years and ten months; David D., born March 7, 1929, weighed $6 \mathrm{lb} .8 \mathrm{oz}$. at birth, $19 \mathrm{lb}$. at fourteen months, $21 \mathrm{lb}$. at two years, $23 \mathrm{lb}$. at three years, $26 \mathrm{lb} .10 \mathrm{oz}$. at four years, and $32 \mathrm{lb}$. at five years of age. Pearl D., aged 17 years 11 months, is now $3 \mathrm{ft}$. $4 \frac{1}{2}$ in. in height with a head
18 inches in circumference. The head appears small with abundant black silky hair. The face is very striking, prognathous with deeply sunk eyes and partial absorption of orbital fat, the nose prominent and straight, and the central incisors large. The eyeballs are sunken with occluded pupils filled with the remains of lens and capsule following an operation for discission of the lens. The corneae are clear. There are no signs of intraocular infection and the tension is normal. The palate is highly arched and the alveolar margins are thick. She is very thin, with undeveloped breasts, there is no axillary hair, but pubic hair is present. Menstruation began at thirteen years and continued regularly once a month, until she was operated on for cataract two years ago. Since then she has had only two periods, the last seven weeks ago. The feet are cold and blue even on a warm day and there are many small pigmented moles on the arms, legs, and trunk. Physical examination was difficult, but revealed no abnormality of the heart, lungs, or abdomen. The knee jerks were exaggerated and the plantar responses flexor. The hands appear unduly large; there is limited flexion at the first metacarpo-phalangeal joint of both hands, and to a slight extent at the second, but the movements of other finger joints are full; at the wrists flexion is limited, but extension is full; at the elbows there is slight limitation of extension, but flexion is full, and there is full movement of the shoulders.

The second toes are shorter than the big toes or third toes, the knees show some permanent flexion with contracture of the muscles, but movements at the hips are normal. She is quiet and sits contentedly playing with a piece of string. She can dress herself and blow her nose. She smiled when tickled, but cried when she was undressed. Blindness and deafness make it impossible to assess the degree of mental deficiency. Owing to her struggles it was impossible to carry out a complete X-ray examination of the skeleton and Dr. Kemp was dissatisfied with the X-ray of the skull. He reports that the skull bones are very thick, but could not see the outline of the pituitary fossa clearly.

Three days after admission to the hospital she had a sudden attack marked by stertorous breathing and a very rapid irregular pulse. On auscultation pulsus bigeminus was present and the beats were fluttering in character. On injection of $\frac{1}{2}$ to 1 c.c. of coramin the attack ceased abruptly and the cardiac rhythm was restored to normal. The mother stated that she had had one similar attack previously, 
though not so severe. When the coramin was given it was noted that there was a latent period of about three seconds before any pain response to the prick occur red and then there was a violent protest.

DAvid D., aged 16 years and 3 months, is $3 \mathrm{ft} .8 \frac{1}{2}$ in. in height with a head 19 inches in circumference. His mother stated that he went to school at $5 \frac{1}{2}$ years, but could not be taught anything at an ordinary school. It was discovered that he

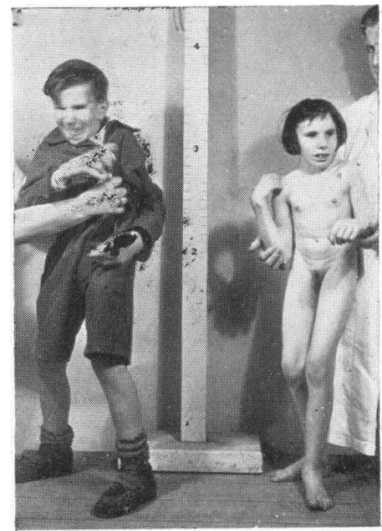

FIG. 1.

was deaf and he was transferred to a school for the deaf at Exeter, where he began to make some progress. He then got rubella and has neither spoken nor heard much since. He has not been to school for six years. His sight was fairly good, but has been failing for six years, though he is not yet blind. On examination he appears to be intelligent, but being almost completely deaf and nearly blind, it is impossible to determine his mental level. His visual acuity is between $3 / 60$ and $6 / 60$. Both lenses show dense but thin opacities, which blur the picture of the fundus. The optic discs can, however, be seen and show a condition of primary optic atrophy, being dead white with very small vessels. The fundus cannot be seen well enough to make any statement about the pigmentation, which was noted ten years ago. Treatment for his eyes was tried by means of atropine, as the opacity seemed to be slightly denser in the centre of the lens than at the periphery. The pupils dilated, but visual acuity did not appear to be improved. Needling of the lens was not advised on account of the optic atrophy, which is the chief cause of his poor sight at present.

$\mathrm{He}$ is able to dress himself, buttoning his shirtcuffs with one hand, and put on his shoes, tying the laces quickly and neatly. When I saw him he put one stocking on the wrong way round, but twisted it round at once. Indoors he is very fond of playing with an electric torch, but prefers to be out of doors. He is said to help his father, who is a woodcutter, using a small billhook and stacking wood. He smiled and was friendly at first, but resisted attempts to examine him, struggling, trying to pinch and kick, and weeping with rage. As soon as he was allowed to dress his violent temper passed and he became friendly again.

$\mathrm{He}$ is thin with medium brown hair and blue eyes, a long prominent nose and deep-set eyes. He has a high narrow palate, broad alveolar margin, and his teeth are carious. The skin is rough and dry, that on the face peeling from sunburn, and his feet are cold and blue, but not as bad as his sister's. Examination of the chest and abdomen disclosed no

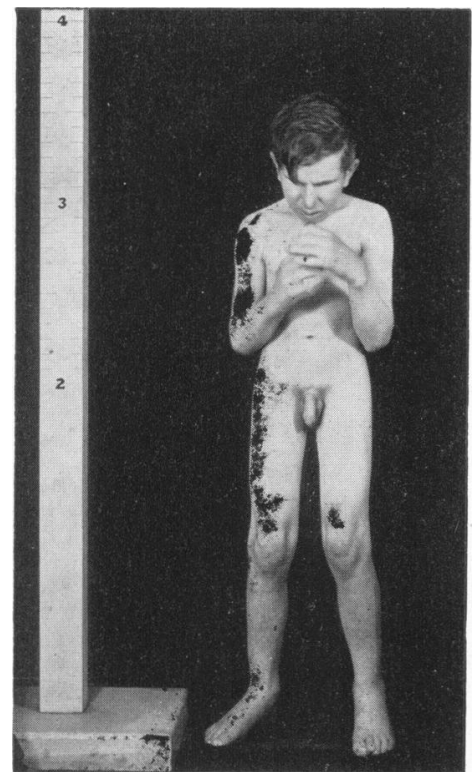

FIG. 2.

abnormality. There is no axillary hair, the pubic hair has a feminine distribution, the size of his penis is proportionate to his stature, the right testis is rather small and the left undescended. The knee

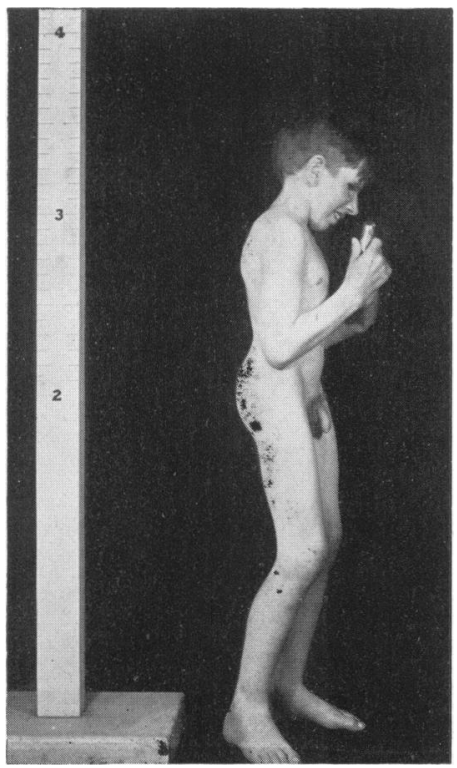

FIG. 3.

and ankle jerks are present, but it is not possible to test the plantar response. The urine is acid with a trace of protein, but no sugar, and occasional leucocytes and epithelial cells were seen. The 
hands are large and the finger joints appear to be swollen. There is limited flexion of the thumbs and first fingers at the metacarpo-phalangeal joint, at the wrist extension is greatly limited, but flexion is full. The knees are slightly flexed and the right cannot be straightened owing to contracture of the muscles. The second toe of the left foot is shorter than the big toe, but the right foot is normal. Movement at the hip joints is normal. He does not walk as well as he did and is apt to stumble and fall, but this may be due to failing eyesight.

Dr. F. H. Kemp was only able to take X-rays of the hands and skull. He reports that the degree of skeletal maturity is normal for his age, and that the bones are small and the skull is very thick.

The condition, which is probably recessive, appears to be a definite entity not previously described. It is characterized by dwarfism with prognathism, thickening of the skull bones and other skeletal changes, a peculiar form of retinal pigmentation, optic atrophy, and cataract, deafness, and mental deficiency. The extremities are cold and blue. If it is possible to keep in touch with the children, it will be interesting to see whether further changes take place in later life.

I am very much indebted to Professor Ida Mann for allowing me to examine the children again and for her report on the state of their eyes, and to Dr. F. H. Kemp for taking X-rays of their skulls and hands.

\section{REFERENCE}

Cockayne, E. A. (1936). Arch. Dis. Childh., 11, 1. 